\title{
The Impact of WhatsApp on Learners' Achievement: A Case Study of English Language Majors at King Khalid University
}

\author{
Abdulkhaleq Q. A. Hassan \\ King Khalid University, Saudi Arabia \\ PO: 960, ZIP code: 61421, Abha, Saudi Arabia \\ Tel: 966-536-347-107Ｅ-mail: almakhdari@gmail.com

\begin{abstract}
Sayed Salahuddin Ahmed (corresponding author)
King Khalid University, Saudi Arabia

PO: 960, ZIP code: 61421, Abha, Saudi Arabia
\end{abstract} \\ Tel: 966-532-255-706_E-mail: green23feb@gmail.com
}

Received: September 5, 2018 Accepted: October 3, 2018 Published: October 7, 2018

doi:10.5296/ijele.v6i2.13743 URL: https://doi.org/10.5296/ijele.v6i2.13743

\begin{abstract}
To investigate the effectiveness of e-learning by using a particular mobile application, namely WhatsApp, an empirical study was conducted on sixty undergraduate English language majors at King Khalid University in Saudi Arabia. The objective of the study was to determine whether the levels of motivation, content knowledge and grades of the students (who took the course "Syntax")-, developed after receiving additional support through WhatsApp apart from traditional classroom lectures. The results showed that the experimental group that got extra support from fellow students and the course teachers through WhatsApp outperformed the students of the control group who studied the course only through traditional method. Moreover, the gap of success rate between the experimental group and the control group is about eighty nine percent with zero failure in the experimental group. The study proved that WhatsApp can be effectively used for providing supplementary support to motivate students to study properly and to get higher grades.
\end{abstract}

Keywords: Syntax, WhatsApp, English language learning, Motivation, achievement 


\section{Introduction}

\subsection{Background}

At King Khalid University, a good number of students have complained to the course teacher (CT) that the course "Syntax" is difficult and challenging which affects their overall grade. Many of them failed in the course several times. Students' frustration about the course and the gloominess that hovered around the class led the (CT) to investigate into the real reasons for such disappointing results in the course. After talking to former and present students individually and in groups, they realized that studying theoretical structures of English language was difficult to the students for several reasons, like poor background knowledge in English language that they carry from high school, lack of motivation to study as well as improper study habit. The CT found some other problems as well such as, large classes, students' high absenteeism, unavailability of students' common room for discussion, insufficient co-curricular and extra-curricular activities, etc. Thus regular classes are not sufficient to solve all the problems. Moreover, many students feel shy to speak in the classroom due to incompetence in English language. The CT offered 10 hours per week for consultation in their offices but a few of the students turned up. Furthermore, there was no opportunity for addressing a group of students together for consultation or initiating the scopes for sharing information among the learners. The CT looked for an opportunity to reach students outside formal classes. The CT observed that every student in the class possesses at least one smart phone and everybody uses WhatsApp. WhatsApp is a free messenger application for smartphones. It uses internet to send messages, images as well as audio and video clips. The cost of WhatsApp use is less than texting. Students spend several hours a day on social media including Whatsapp. So, the CT thought it would be a great idea to use learners' passion as a tool for teaching them syntax that they consider 'difficult'. The hypothesis was: as the real classroom failed to motivate the learners properly to study, the virtual world might be able to provide them with additional support and motivation. Also, it would make the course easy and enjoyable. So, the CT did the experiment by dividing the class into two groups - control group and experimental group. Eventually, the CT formed a WhatsApp group for the experimental group and offered counseling, motivation as well as other study-support through the group.

\subsection{Research Problem}

The Kingdom of Saudi Arabia is one of the leading Internet using countries in the world. Global Media Insight (GMI), a Middle East based market research organization, in its statistics of 2018, mentioned that the number of Internet users in Saudi Arabia leaped up to 30 million. The Kingdom has got 25 million active social media accounts, 18 million active mobile social network accounts and 24.27 million WhatsApp accounts. At King Khalid University, students spend several hours a day on social media. Ahmed \& Hassan (2017) conducted a study on the use of Internet by the students of King Khalid University in Saudi Arabia and found that students use the internet mainly for entertainment though they rarely use the same for educational purposes. Most of the students are not even introduced to the multi-faceted use of the Internet. So, when the students of the course "Syntax" shared the 
difficulties they face in the course, the CT analyzed the whole situation: attitude, preferences and life style of the learners, availability and lacking of the infrastructural support, etc., and designed the alternative teaching route with the help of WhatsApp. The CT utilized learners' passion as a tool for leaning and motivation.

\section{Literature Review}

\subsection{Use of Technology in English Language Learning}

With the help of technology, now people can learn English at preferred time and place. Technology has also aided formal education of the language by broadening the opportunities of interaction and sharing. Prensky (2001) opines that students have adopted new instructional technologies in learning as well as constructing knowledge. Attewell (2005) developed an SMS-based course so that learners get motivated to study foreign language through mobile phones. The study concluded that the learners improved reading comprehension skill. Cavusand (2008) investigated the use of wireless technologies in education, in particular, learning new technical English words by using Short Message Service (SMS). The results of the study indicate that students enjoyed using their mobile phones to learn new words. They concluded that using the Mobile Learning Tool System (MOLT) proved to be an effective educational tool. Rambe and Bere (2013) used mobile instant messaging system to make alternative route for learners' collaboration in an informal manner because of limited lecture hour and students' lack of participation. The researchers used WhatsApp as a learning tool. Results revealed that WhatsApp motivated students to get connected to each other and study properly. Students found the online discussion interactive and flexible compared to traditional lectures. The roles of teachers have been changed to facilitators, so the learners' roles have changed to generators, collaborators and group leaders. Alfaki and Alharthy (2014) studied the impact of social networks to promote learners' English language skills. They collected data through pre- and post-tests. Two groups of 80 participants were selected. Results showed that learning through social networks was more effective than traditional classroom teaching. Cakir (2015) studied the use of mobile phones in foreign language teaching from teachers' perspective. A total of 193 English language teachers participated in the survey. Results showed that most of the teachers preferred to use their mobile phones as instructional tools. Researchers as well as English language teachers have proved the importance of technology in teaching English. Lacina (2004), Edmodo (2010), Saxena (2013), Altun (2015), Dehghanpour and Hashemian, (2015) enumerate a number of benefits that technology can bring, e,g. (1) teachers can share their experiences related to teaching and learning; (2) it encourages independent learning on the part of students; (3) it enhances students-teacher interaction that saves time and space (4) use of social media increases the interaction among the learners and they can study in groups in the virtual world (5) the virtual learning space created by technology can be used as substitute of the physical classes as very often real classes fail to serve the needs of the students for many problems, like large number of students, limitation of time, lack of infrastructural support, learners' shyness, etc (6) learners can connect to the CT more easily in the virtual world 
rather than the real world (7) learners feel free to open up themselves to the teacher and fellow students in the social media. Gooniband Shooshtari, Jalilifar, and Khazaie (2013) examined the use of mobile devices on teaching English vocabulary items and found that the use of application was successful in the performance of the semi-illiterates. Taki and Khazaei (2011) investigated the use of mobile phone to present vocabulary in written and pictorial forms. The findings showed that the participants who used mobile phone applications performed better when they studied word with pictorial or written annotations. Başoğlu (2010) concluded that the participants who used the mobile application remembered the words better than them who studied in traditional methods. Stickler and Hampel (2010) found that online language course can combine different approaches to learning and teaching, such as using language communicatively and focusing on form and language practice. Tabatabaei and Heidari Goojani (2012) measured the effectiveness of using SMS in teaching L2 vocabulary to Iranian EFL students. Their results showed the effectiveness of using tools related to the students' digital age. Yousef zadeh (2012) examined the superiority of mobile phone-based method on paper-based method in learning collocation words. Chen (2008) investigated the use of mobile phones for the delivery of vocabulary materials to English learners in Taiwan. The results showed that the EFL learners preferred using their phones because of easy access to materials and the ability to practice anytime, anywhere. Stockwell (2007) showed that learners' vocabulary increased due to using the mobile-based vocabulary learning applications. Thornton and Houser (2005) examined the use of mobile devices in a language learning context. The results showed that the students evaluated educational materials designed for mobile phones very positively. The researchers also found mobile phones very effective for vocabulary learning.

\subsection{Use of WhatsApp in Learning English Language}

WhatsApp is one of the most popular social networks in the entire world especially among the youths. English language teachers and researchers around the world have carried out studies to check the validity of WhatsApp as a language learning tool. Amry (2014) conducted a study to explore the impact of using WhatsApp on the achievement and attitudes in learning English language. The researcher selected 30 students in two groups-experimental and control. The e-learning process of the experimental group depended on WhatsApp, whereas the process of the control group was only face-to-face learning in the classroom. The t-test was used to compare the differences between the experimental and control groups. Results showed that there are differences at 0.05 alpha level in the achievements and attitudes of the experimental group compared to the control group. AbdAlfattah (2015) ran a study to check the effectiveness of using a WhatsApp Messenger as one of mobile learning techniques to develop students' writing skills. Participants were 30 second year college students of English department from a private university in Saudi Arabia. They were divided into two groups (experimental and control). The experimental group used WhatsApp technology to develop their writing skills; whereas, the control group was taught the same skill in the classroom. Results revealed that WhatsApp technique had positive effects on the experimental group compared to control group. Alhawiti (2015) examined the effects of WhatsApp on learning English for Specific Purposes (ESP) at the community college of 


\section{Ml Macrothink}

Tabuk in Saudi Arabia. The sample consisted of 36 students from the Department of Business Administration. They were divided into two groups. The control group was taught through conventional methods, while Whastapp was used for the experimental group. Findings showed that the experimental group exhibited higher progress in ESP post-test compared to control group. Ta'mneh (2017) observed that the WhatsApp application in teaching English language improved the abilities of the learners. It provides access to learning resources when teachers and students are separated by time and distance (Honeyman \& Miller, 1993). Philip Haines, Senior Consultant for Oxford University Press, Mexico as well as a teacher and teacher trainer, provided 25 engaging and useful classroom activities for language learners using WhatsApp. (Oxford, 2016). Mwakapina, Job W. (2016) realized that WhatsApp plays a great role to the largest extent in helping students learn English interactively and collaboratively. It was reflected that the benefits of blending traditional method and the use of WhatsApp in L2 classroom far outweighed the challenges.

\section{Methodology}

\subsection{Research Questions}

1. Are there any marked difference between the performance of the Experimental Group and the Control group? What were the reasons behind that?

2.How does WhatsApp help students in studying the course "Syntax"?

3. How does WhatsApp motivate students to study and achieve better grades?

\subsection{Research Framework}

\subsubsection{Participants}

All the participants of the study were male students due to gender segregation in the universities in KSA. 60 male undergraduate students at the Department of English, College of Science and Arts, King Khalid University took part in this study. They are all native speakers of Arabic and their ages range from 21 to 26. They were homogeneous in terms of their linguistic and socioeconomic backgrounds. They all have started learning English between the age of 12 and 13. They were divided equally into two groups - Control Group (CG) and Experimental Group (EG).

\subsubsection{Date Collection}

The data were collected through two instruments - tests and questionnaires. The tests included first midterm test, second midterm test and final test. The first midterm test was conducted in the seventh week, the second in the fourteenth week and the final in the seventeenth week of the semester. All the tests were studied and evaluated carefully. Moreover, the participants of the EG were given a questionnaire of 15 items on Five-Point Likert scale.

The CG studied the course "Syntax" throughout the semester in the traditional format. They 
had 34 lectures ( 2 lectures per week, each of 90 minutes) in 17 weeks in total, including 2 midterm tests. Moreover, the CT offered 10 hours per week for consultation in his office. Apart from these meetings, students did not have any other way to contact the CT. The progress of the course was assessed through blackboard quizzes for 10 marks, two midterm tests each of 20 marks and the final exam of 50 marks. Final grade sheets of all the students were evaluated to examine the progress of the students. The EG completed all the procedures just as the CG did. In addition to that, the EG received the following additional support for the course through WhatsApp group:

1. The WhatsApp group allowed the EG members to share problems and ideas among themselves 24 hours 7 days a week. They could use different options of the network e.g. chatting, calling, video chatting, document sharing, etc. to interact with each other.

2. On the WhatsApp group, The CT was online from 8 PM to 10 PM every night except Fridays. Students of the group were encouraged to chat, talk and also video chat individually and in groups with the CT to solve the problems they faced in the course.

2. The CT shared many documents and video clips with the learners which were very useful to study the course.

3. All students, including the shy and introvert ones had the opportunity to share their problems with the CT and the fellow students on WhatsApp.

4. Learners discussed problems and their ideas among themselves while the CT monitored the whole discussion and intervened when necessary.

5. The CT discussed students' the errors individually and in groups with students made.

6. EG members could share their problems and opinions with the fellow students of the group as well as the CT throughout the week. If they faced any trouble in studying the course, they could post questions on the WhatsApp group and other students would come up with the answers. Finally, the CT observed the conversations and presented his feedback.

\subsubsection{Data Analysis}

Ahmed, S \& Hassan, A. (2017) found that WhatsApp topped the social media applications at King Khalid University as 100 out of 115 of the students used WhatsApp for different purposes. So, in an attempt to utilize WhatsApp for educational purposes, an experimental study was conducted on 30 students of level seven students. The rest of the class (30 students) was used as a control group. Members in the experimental group were selected randomly.

The students were given instructions at the beginning of the semester on how to participate in this experiment. They were asked about the preferred time for using WhatsApp for this purpose. At the end of the semester, a questionnaire was given to them to fill it in. The final results of the two groups were separated and studied carefully. The results of the experiment group were better than the results of the control group. Surprisingly, no one failed from the experiment group whereas 15 students failed from the control group.

Table and graph 1 (Appendix 1) exhibit that the performance of the experimental group was 
better than that of the control group. Five students out of thirty, with a percentage of almost 17, got A and A plus; nineteen students obtained B \& B plus with a percentage of 63 and the remaining 6 students secured $\mathrm{C} \& \mathrm{C}+$. Surprisingly, no student from the experimental group failed in this course; whereas, 50 percent of the students of the control group failed this course.

The date were analyzed by the Statistical Package for Social Sciences, SPSS ,V.23 where the following results were obtained:

Table 1. Descriptive statistics of the control group and experimental group.

\begin{tabular}{|l|c|c|c|c|c|}
\hline & $\mathrm{N}$ & Minimum & Maximum & Mean & Std. Deviation \\
\hline Experimental Group & 30 & 70.00 & 95.00 & 82.57 & 6.786 \\
\hline Control Group & 30 & 27.00 & 93.00 & 58.87 & 15.64 \\
\hline
\end{tabular}

Table 2. Analysis of variance (ANOVA)

\begin{tabular}{|l|r|r|r|r|r|}
\hline & \multicolumn{1}{|c|}{ Sum of Squares } & df & Mean Square & \multicolumn{1}{c|}{ F } & \multicolumn{1}{c|}{ Sig. } \\
\hline Between Groups & 1298.200 & 25 & 51.928 & 5.589 & .053 \\
\hline Within Groups & 37.167 & 4 & 9.292 & & \\
\hline Total & 1335.367 & 29 & & & \\
\hline
\end{tabular}

Table 3. Paired Samples Test

\begin{tabular}{|c|c|c|c|c|c|c|c|c|c|}
\hline & \multicolumn{5}{|c|}{ Paired Differences } & \multirow[b]{3}{*}{$\mathrm{t}$} & \multirow[b]{3}{*}{$\mathrm{df}$} & \multirow[b]{3}{*}{$\begin{array}{c}\text { Sig. } \\
\text { (2-tailed) }\end{array}$} \\
\hline & & \multirow[b]{2}{*}{ Mean } & \multirow[b]{2}{*}{$\begin{array}{c}\text { Std. } \\
\text { Deviation }\end{array}$} & \multirow{2}{*}{$\begin{array}{l}\text { Std. } \\
\text { Error } \\
\text { Mean }\end{array}$} & \multicolumn{2}{|c|}{$\begin{array}{l}95 \% \text { Confidence } \\
\text { Interval of the } \\
\text { Difference }\end{array}$} & & & \\
\hline & & & & & $\begin{array}{c}\text { Low } \\
\text { er }\end{array}$ & Upper & & & \\
\hline Pair 1 & $\begin{array}{l}\text { Exp. Group - } \\
\text { Control } \\
\text { Group }\end{array}$ & 23.70 & 11.41 & 2.083 & $\begin{array}{r}19.4 \\
4\end{array}$ & 27.96 & 11.37 & 29 & .000 \\
\hline
\end{tabular}


The tables show that the minimum mark that was obtained by the student of the experiment group was seventy whereas the minimum for the control group was twenty seven. The mean for EG was 82.566 and the mean for CG was 58.866. The standard deviation for the EG was 6.785 and the standard deviation for CG was 15.636 which means that the data for the CG spread out over a wider range than for the EG.

The $\mathrm{f}$ is at 5.589 and the $\mathrm{p}$-value is at .053 which shows that there was a statistically significant difference between mean scores of the Experimental group (EG) and the control group (CG).

\section{Conclusion}

The study has yielded significant insights. First, for the use of WhatsApp, students of the experimental group secured a considerable achievement in the course with a big leap on grades with zero failure. Second, the fear that the students of the experimental group had regarding the course "Syntax" has been removed and made them feel more confident and positive towards learning English language. Third, the experimental group members had a regular interaction among fellow members as well as the course teachers which has made them social and interactive. Fourth, they have been introduced to the use of technology for learning which makes them use the same to study other courses as well.

This study is a preliminary one of a series of studies we have planned to do on a number of English language courses to examine the reliability and validity of Whatsapp for the teaching- learning of English. If we find Whatsapp as a reliable application for learning English after completing the battery of tests, we will recommend the university to include Whatsapp-aided instruction in the curriculum. Were there any limitations or challenges to the study? The profile does not make mention of the student gender?

\section{Limitations:}

1. The study was conducted only on male students as Kingdom of Saudi Arabia maintains strict Islamic regulation about the free-mixing of men and women.

2. The research was operated only on 60 students which is not a standard number to reach the conclusion that Whatsapp can be used unanimously for all English courses. But have mentioned that this study is the first one of a battery of tests planned to be conducted soon to cross-check the reliability of Whatsapp for other English language courses.

What was the outreach of the data collection, i.e. 60 students participated in the study. Is it enough to draw the conclusion that Whatsapp can be implemented wholesale on large groups of the student population?

What are the implications of the findings? 


\section{Acknowledgement}

The authors are grateful to King Khalid University for providing financial and technical support for this study.

\section{References}

AbdAlfattah, S. (2015). The Effectiveness of Using a WhatsApp Messenger as One of Mobile Learning Technique to Develop Students' Writing Skills. Journal of Education and Practice, 6,32 .

Ahmed, S., \& Hassan, A. (2017). A Study on the Rationale of Social Media Use by the Students of King Khalid University. English Language Teaching, Vol. 10, No. 8; 2017.

Alfaki, I., \& Alharthy, K. (2014). Towards a Digital World: Using Social Networks to Promote Learner's Language. American International Journal of Contemporary Research, 4, 10.

Alhawiti, M. (2015). The Effect of Mobile Language Learning on ESP Students' Achievement. Journal of Modern Education Review, 5(3), 272-282.

Altun, M. (2015). The Integration of Technology into Foreign Language Teaching. International Journal on New Trends in Education and their Implications, 6(1). Retrieved from www.ijonte.org

Amry, A. (2014). The Impact of Using WhatsApp Mobile Learning Activities on the Achievement and Attitudes of Online Students Using Mobile Devices at the University. European Scientific Journal August., 10, 22.

Attewell, J. (2005). Mobile technologies and learning: A Technology Update and M-learning Project Summary. London: Learning Skills Development Agency.

Başoğlu, E. B. (2010). A Comparison of Undergraduate Students' English Vocabulary Learning: Using Mobile Phones and Flashcards. Educational Technology, 9(3), 1-7.

Cakir, I. (2015). Opinions and Attitudes of Prospective Teachers for the Use of Mobile Phones in Foreign Language Learning. Contemporary Educational Technology, 6(3), International Research in Education ISSN 2327-5499 2017, Vol. 5, No. 1151 http://ire.macrothink.org 239-255.

Cavus, N., \& Ibrahim, D. (2008). M-Learning: An Experiment in Using SMS to Support Learning New English Language Words. British Journal of Educational Technology, 40(1), 78-91.

Chen, C. H. (2008). Why Do Teachers Not Practice What They Believe Regarding Technology Integration? Journal of Educational Research, 102, 65-75. http://dx.doi.org/10.3200/JOER.102.1.65-75

Dehghanpour, E., \& Hashemian, M. (2015). Efficiency of Using a Web-based Approach to 
Teach Reading Strategies to Iranian EFL learners. English Language Teaching, 8(10), 11-25.

Devarajana, S., Mongab, C., \& Zongo, T. (2012). Making Higher Education Finance Work

Edmodo (2010). Edmodo: Tour (tour link). Retrieved from http:// www.edmodo.com Is this a primary reference or a secondary reference?

Gass, S., \& Mackey, A. (2007). Data Elicitation for Second and Foreign Language Research. London: Routledge.

Gooniband Shooshtari, Z., Jalilifar, A., \& Khazaie, S. (2013). Mobile, L2 Vocabulary Learning, and Fighting Illiteracy: A Case Study of Iranian Semi-illiterates Beyond Transition Level. Applied Research on English Language, 2(2), 65-79.

Honeyman, M., \& Miller, G. (1993). Agriculture Distance Education: A Valid Alternative for Higher Education? Proceedings of the 20th Annual National Agricultural Education Research Meeting, 67-73.

Lacina, J. (2004). Promoting Language Acquisitions: Technology and English Language learners. Childhood Education, 81(2). Retrieved form http://eric.ed.gov/?id=EJ709112

Mwakapina, Job W. (2016). WhatsApp Mobile Tool in Second Language Learning: Opportunities, Potentials and Challenges in Higher Education Settings in Tanzania. International Journal of English Language Education. Vol. 4, No. 2.

Oxford Uuversity Press. (2016). 25 Ideas for Using WhatsApp with English Language Students. Retrieved from https://oupeltglobalblog.com/2016/05/17/25-ideas-for-using -whatsapp-with-english-language-students/

Prensky, M. (2001). Digital Natives, Digital Immigrants Part 1. On the Horizon, 9(5), 1-6.

Rambe, P., \& Bere, A. (2013). Using Mobile Instant Messaging to Leverage Learner Participation and Transform Pedagogy at a South African University of Technology. British Journal of Educational Technology, 44(4), 544-561

Sanaz Jafari \& Azizeh Chalak. (2016). The Role of WhatsApp in Teaching Vocabulary to Iranian EFL Learners at Junior High School. English Language Teaching, Vol. 9, No. 8; 2016 ISSN 1916-4742 E-ISSN 1916-4750.

Saxena, S. (2013). Using Technology in Education: Does it Improve Anything? Retrieved from http://www.edtechreview.in/news/681-technology-in-education

Stickler, U., \& Hampel, R (2010). Cyber Deutsch: Language Production and User Preferences in a Moodle Virtual Learning Environment. CALICO Journal, 28(1), 49-73. http://dx.doi.org/10.11139/cj.28.1.49-73

Stockwell, G. (2007). A Review of Technology Choice for Teaching Language Skills and Areas in the CALL Literature. ReCALL, 19(2), 105-120. http://dx.doi.org/10.1017/S0958344007000225

Tabatabaei, O. \& Heidari Goojani, A. (2012). The Impact of Text-Messaging on Vocabulary 


\section{Macrothink}

Learning of Iranian www.ccsenet.org/elt English Language Teaching Vol. 9, No. 8; 201692 EFL Learners. Cross Cultural Communication, 8(2), 47-55.

Taki, S., \& Khazaei, S. (2011). Learning Vocabulary via Mobile Phone: Persian EFL Learners in Focus. Journal of Language Teaching and Research, 2(6), 1252-1258. http://dx.doi.org/10.4304/jltr.2.6.1252-1258

Ta'amneh, Mohammad Abd Alhafeez Ali. The Effect of Using WhatsApp Messenger in Learning English Language among University Students. (2017). International Research in Education Vol. 5, No. 1. http://dx.doi.org/10.5296/ire.v5i1.10801

Thornton, P., \& Houser, C. (2005). Using Mobile Phones in English Education in Japan. Journal of Computer Assisted Learning, 21, 217-228. http://dx.doi.org/10.1111/j.1365-2729.2005.00129.x

Yousef Zadeh, M. (2012). Mobile-based Learning vs. Paper-based Learning and Collocation words Learning. Journal of Educational and Instructional Studies, 2(3), 216-220.

\section{Appendix 1}

\begin{tabular}{|c|c|c|c|c|c|c|}
\hline \multirow{2}{*}{$\begin{array}{l}\text { Groups } \\
\text { marks }\end{array}$} & $90-100$ & $80-89$ & $70-79$ & $60-69$ & $0-59$ & \multirow[b]{2}{*}{ total } \\
\hline & $\begin{array}{c}A+\& \\
A\end{array}$ & $\mathrm{~B}+\& \mathrm{~B}$ & $\mathrm{C}+\& \mathrm{C}$ & $D+\& D$ & $\mathrm{~F}$ & \\
\hline \multirow[t]{2}{*}{ Experiment group } & 5 & 19 & 6 & 0 & 0 & 30 \\
\hline & $16.66 \%$ & $63.33 \%$ & $20 \%$ & 0 & 0 & 100 \\
\hline \multirow[t]{2}{*}{ Control group } & 1 & 2 & 5 & 7 & 15 & 30 \\
\hline & $3.33 \%$ & $6.66 \%$ & $16.66 \%$ & $23.33 \%$ & $50 \%$ & 100 \\
\hline
\end{tabular}

Table Distribution of grades 


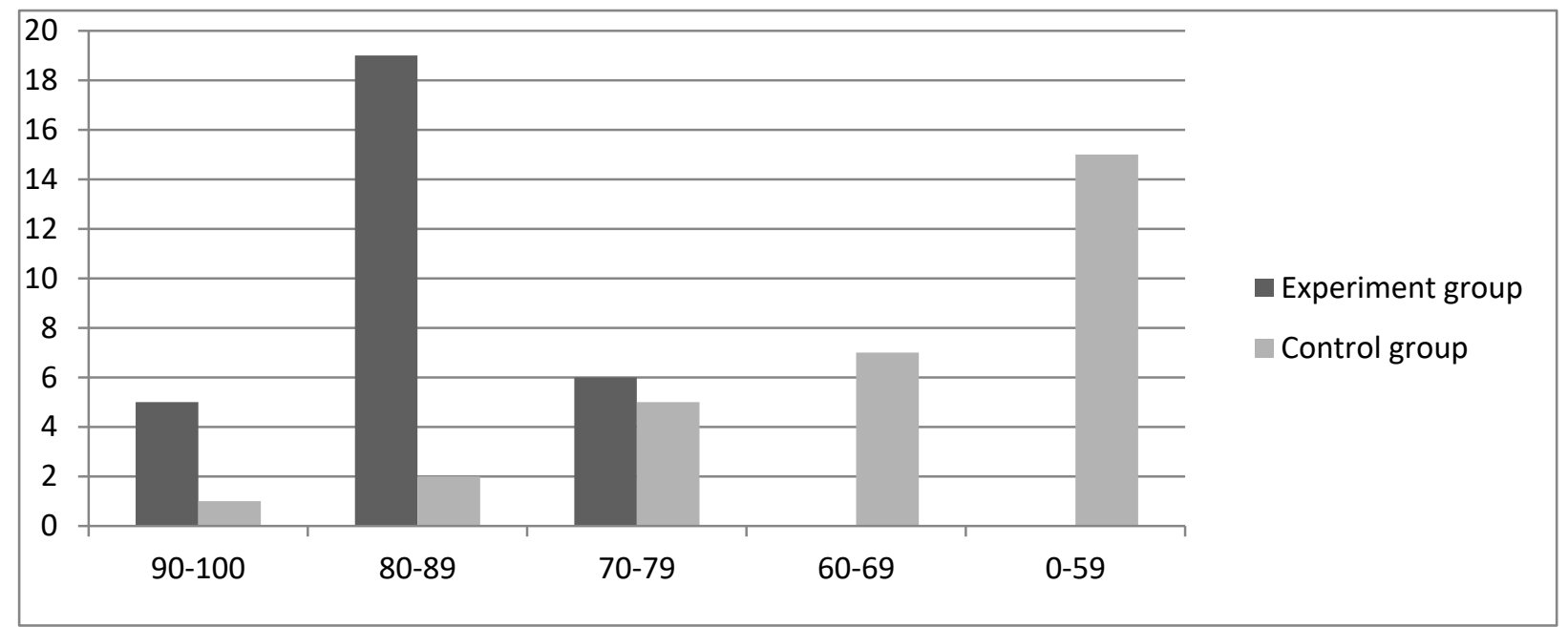

Graph 1: Distribution of Students' grades

\section{Appendix 2}

Questionnaire

1) I spend more than four hours on WhatsApp everyday.
a) strongly agree
b) agree
c)uncertain
d) disagree
e) strongly disagree.

2. The teacher asked me about the preferable time for using WhatsApp.
a) strongly agree
b) agree
c)uncertain
d) disagree
e) strongly disagree.

3. WhatsApp helped me get better grades in this course.
a) strongly agree
b) agree
c)uncertain
d) disagree
e) strongly disagree.

4. WhatsApp helped me to increase content-knowledge in this course.
a) strongly agree
b) agree
c)uncertain
d) disagree
e) strongly disagree.

5. Teacher was cooperative and responsive to my questions and queries.
a) strongly agree
b) agree
c)uncertain
d) disagree
e) strongly disagree.

6. I responded to the questions raised by the teacher and other students without delay.
a) strongly agree
b) agree
c)uncertain
d) disagree
e) strongly disagree.

7. The members of the WhatsApp group were cooperative.
a) strongly agree
b) agree
c)uncertain
d) disagree
e) strongly disagree.

8. I want WhatsApp learning group applied for all courses. 


\section{Macrothink}
a) strongly agree
b) agree
c)uncertain
d) disagree
e) strongly disagree.

9. I felt uncomfortable when the teacher asked me questions in the class.
a) strongly agree
b) agree
c)uncertain
d) disagree
e) strongly disagree.

10. Using WhatsApp for this course motivated me to study properly.
a) strongly agree
b) agree
c)uncertain
d) disagree
e) strongly disagree.

11. The teacher used media (audio and video) for teaching purposes.
a) strongly agree
b) agree
c)uncertain
d) disagree
e) strongly disagree.

12. The teachers sent us a lot of web links related to this course.
a) strongly agree
b) agree
c)uncertain
d) disagree
e) strongly disagree.

13. The media related to the course the teacher sent were useful.
a) strongly agree
b) agree
c)uncertain
d) disagree
e) strongly disagree.

14. using WhatsApp for this course encouraged me to ask and answer questions.
a) strongly agree
b) agree
c)uncertain
d) disagree
e) strongly disagree.

15. I feel satisfied with what I have achieved in this course.
a) strongly agree
b) agree
c)uncertain
d) disagree
e) strongly disagree.

\section{Copyright Disclaimer}

Copyright for this article is retained by the author(s), with first publication rights granted to the journal.

This is an open-access article distributed under the terms and conditions of the Creative Commons Attribution license (http://creativecommons.org/licenses/by/3.0/). 